\title{
Outsourcing in Positive Law and Practice in Indonesia
}

\author{
Rd. Danny Zulkarnaen \\ Human Resource Management, State University of Jakarta \\ Rawamangun, Jakarta Timur, Indonesia \\ E-mail: zoenavy1967@gmail.com
}

Hady Efendy

Titan Mineral Utama, Tangerang, Indonesia

E-mail: efendy_hady@yahoo.co.id

Received: Sept. 14, 2017 Accepted: Sept. 26, $2017 \quad$ Published: Oct. 11, 2017

doi:10.5296/csbm.v4i2.11867ＵRL: http://dx.doi.org/10.5296/csbm.v4i2.11867

\begin{abstract}
Outsourcing is a matter worded in the Labor Act and the latest issue in relation to Indonesia labor. It is ruled in terms of easing employers to manage the company in providing the labor service. The implementation is regulated strictly in Article 64-66 of the Act Number 13, 2003 regarding the labor. However, in the implementation level the violation is unavoidable causing the trouble. It happens as the outsourcing is defect both the legislation and implementation. Arrangement concerning of outsourcing in Law Number 13 Year 2003 concerning labor, at one side have opened opportunity of new companies appearance which active in service, and on the other side, have enabled companies which have stood to do efficiency through exploiting of service company of outsourcing to product selected service or products which do not in direct correlation to especial business of company. There is no definitive measure him to determine especial as profession and not especial become the reason of justification for entrepreneur to execute outsourcing business regulation the clearness in execution of harmless outsourcing in job relation.
\end{abstract}

Keywords: Employment, Jobs, Labor, Management, Outsourcing 


\section{Introduction}

Outsourcing is to procure the goods or services required by a business or organization based on a contract with an outside supplier. The word is then translated freely into Indonesian into outsourcing which means the transfer of operations jobs) from one company to another. In concise oxford dictionary this term is associated with contract out, to enter into or make a contract, execute or make contract.

Outsourcing is a relatively new concept in the terminology of the language dictionary (David, 2009), the term became popularly used in journal dictionaries from 1979 to 1982. Significantly, the incidence of this terminology seemed to be part of the business effort at the time to reducing obstacles in the workplace (Maynard, 2004). Since the early 1980s, outsourced terminology has grown not only limited to factories but also to being part of the corporate enterprise.

The terminology of outsourcing practice is still relatively new, this practice actually has a long history. When Adam Smith (1995) planned the development of a production labor division in England in the late 18th century, he addressed this in subcontracts and outsourcing agreements. However, outsourcing developed in the 20th century, which further provides an understanding of its meaning and application, is the delegation of daily operations and management of a business process to outsourcing companies. Through delegation, the management is no longer done by the company, but delegated to outsourcing service companies.

In contemporary economies, outsourced jobs evolved from factory activities to functional functions such as human resources, remuneration, marketing, technician support, and customer service. According to Mol (Richad, 2009), in many ways, outsourcing is the same as subcontracting. Activities undertaken by a company may or may be performed by an outsourcer.

In the field of manpower, one of the forms of protection afforded to the people for employment and decent living is governed by the 2003 manpower act which almost comprehensively regulates various fields of employment. The goodwill to provide protection to workers seems to have no meaning with the possible outsourcing system (the provision of workers by the services company) to work for the user company because in reality it raises various problems in the implementation.

Indonesia is a country that has a lot of manpower, but the availability of limited employment unemployment is still relatively large. This condition makes outsourcing more and more increasing throughout the territory of Indonesia as an excuse for the owners of capital to reduce the number of unemployed.

The purpose of this study is twofold. First we review the outsourcing literature with the objective of identifying those references that may provide guidance for managers and researchers. The review of the literature is organized based on the outsourcing decision framework given in Figure 1 (Kremic \& Tukel, 2003). The figure depicts the typical elements of the outsourcing decision and shows where the motivators, benefits, risks, and factors are 
typically encountered in such decisions. Second, the studies in the literature are analyzed based on their content. The aim is to categorize and identify relationships among the studies which are not apparent when the studies are considered individually. The topics discussed in the studies are described by a set of variables and then statistical procedures are applied. The intention here is to identify which topics are commonly discussed together as well as the combinations which seldom appear. In addition, we attempt to form groupings of the studies based on their content, with the objective of identifying areas that need exploration.

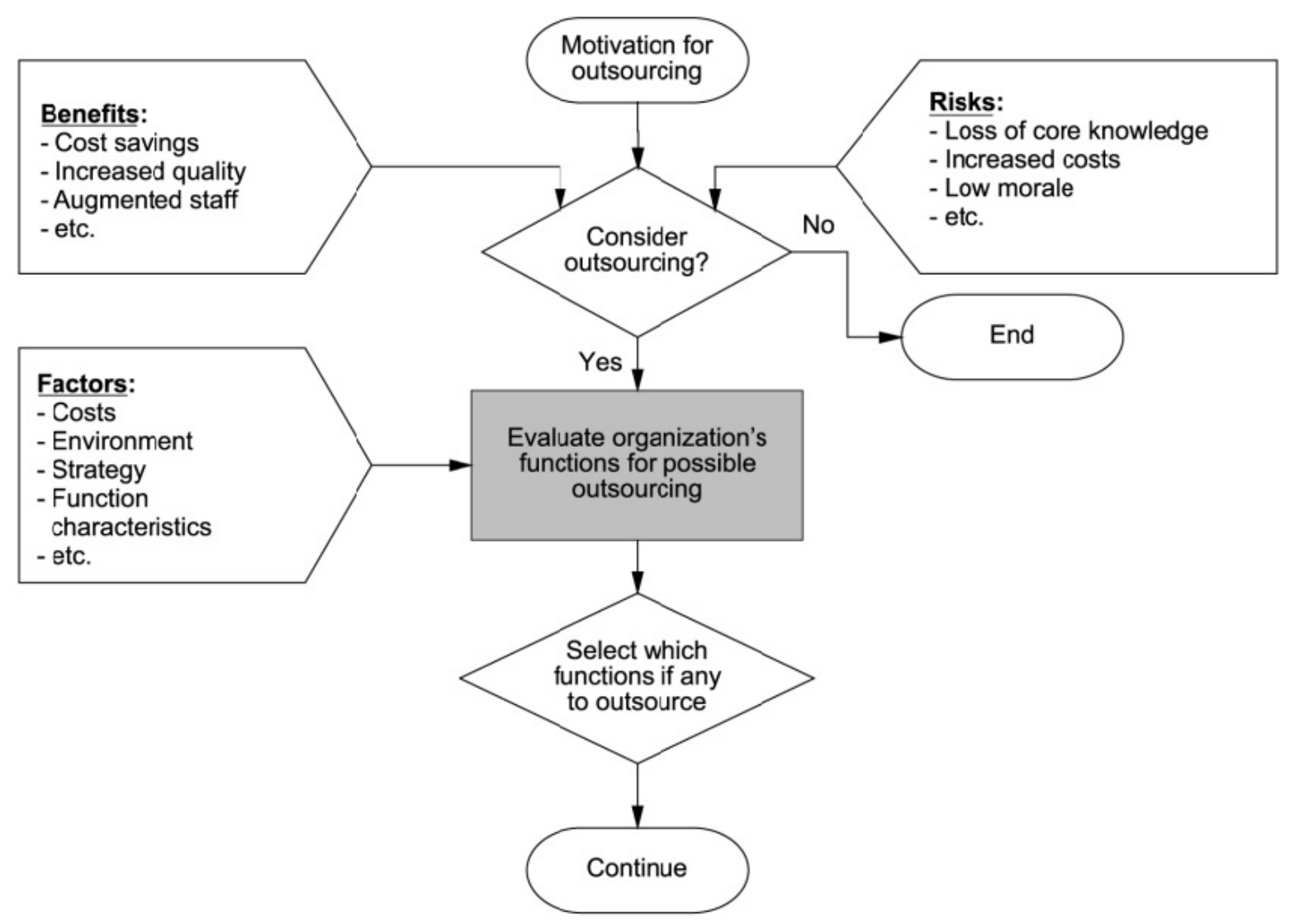

Figure 1. Outsourcing decision framework

The organization of the paper is as follows. We first review the reasons that outsourcing is initiated. What are the outsourcing motivators that are identified in literature? This question is addressed in the second section and may help managers determine if outsourcing is an appropriate option in their situation. The next sections are devoted to identifying the benefits and risks that are commonly expected with outsourcing. A detailed discussion on factors which may impact outsourcing decisions is also provided and followed by the multivariate analyses and the reports on the findings. The last section presents the general conclusions and highlights possible areas for further research. Based on the above description, this article will discuss the outsourcing agreement in the labor law in Indonesia and try to examine the issue of outsourcing in terms of legal perspectives and its application. 


\section{Literature Review}

\subsection{Basic Concept of Outsourcing}

The company may deliver a portion of its work to other companies through employment contracting agreements or the provision of services of workers / labor which are made in writing in accordance with the provisions of article 64 of Law No 13/2003. In the implementation of this definition is called outsourcing in accordance with decision of the constitutional court No 27 / PUU-IX / 2011. The agreements are described in articles 65 and 66 of Law No. 13/2003, namely: (1) the delivery of a portion of the work undertaken by the exemption of employment under terms and conditions which must be met if the company uses the system (article 65); and (2) the submission of part of the work through the services of labor along with its terms and conditions (art. 66).

In the context of industrial relations (HI), employment relationships between employers and employees may use a certain time and non-specified employment contract system (paragraph 1 of article 56 of Law No. 13/2003). For the procedures and requirements described in article 59 of Law No. 13/2003. Currently outsourcing has become one of the strategies for companies to improve the effectiveness and efficiency of planning in human resource management, such as recruitment, training programs, personnel administration, retirement or career path programs (Karthikeyan et al., 2011). Traditionally, the most important goal of the outsourcing system is to improve business cost efficiency (Holcomb \& Hitt, 2007; Sutedi, 2009). Using an outsourcing system companies can try to save on expenses to finance the development of company's human resources (Sutedi, 2009). The key to the implementation of outsourcing is to buy services from outside the company, to run activities that are not key competencies, or not related to the core operations and existence of the company. If the company does not have strong capability in the functional area, then the functional area is potentially outsourced. Outsourcing decision-making depends on the amount of added value from outsourcing being the top priority and potential business advantage of the company. In this case, the outsourcing decision is based on business factors as well as technical and risk factors (Lacity et al., 2008).

\subsection{Types of Outsourcing}

Outsourcing is a growing industry in accordance with its competence, although its growth rate is indicated by the number of such firms as companies with different competencies. Given the development of the scale and complexity of outsourcing, the definitions of the specialization that accompany it are also evolving. Common examples of this business function, such as job components: computer programming services; transport and logistics services, tax and accounting services, facilities and housing management, HRM, customer service center. The next trend is to hire contract employees with specialization in recruiting, training, hiring client employees, as well as in health care arrangements and other interests.

Outsourcing that was originally seen only to perform non-primary functions such as personnel, in the last decade in developed countries has become an intelligent management practice. Traditionally, personnel activities have been carried out by internal companies, by 
the end of the 2000s an outsourcing became one of the most important trends in personnel management (Ordanini \& Silvestri, 2008). Increased outsourcing in personnel management, also related to the acceleration of non-transaction activity changes, such as recruitment, selection and training, is a common outsourcing practice (Ordanini \& Silvestri, 2008). The logic of the outsourcing of human resource management functions, as is common in developed countries, including financing efficiency, increased attention to strategic issue issues, improved access to technology and specialized expertise, are as important as improving value and increasing service levels.

Outsourcers are typically divided into two model groups, Business Process Outsourcing (BPO) and Application Service Provider (ASP). In the BPO model, the essentials and assets are transferred from a company to the provider. The process of certain things a company or service and assets of a company submitted to the company outsourcing BPO model. Including the management of customer relations, finance and accounting, HRM and recruitment. This is understood, because these providers will better perform and manage this functionality with agreed service standards and usually at a lower cost.

Enterprise application service providers or Application Service Providers (ASP) provide software on the Internet network and lease it to multiple users. Some applications are common applications, while other customized employee management software is developed by provider companies, this software program can manage salaries, benefits and more. This electronic service is also a human resources management services company based internet network. In addition to these categories, one of the current trends is that companies choose to combine outsourcing and technology to find a model that suits their particular needs. Provider companies provide flexibility to the company through the latest systems and software, the use of networks that enable outside help to manage certain tasks, combined with real-time access to enterprise data, enabling companies to control and control activities.

Companies that outsource significantly, are small to medium-sized companies with between 10 and 1500 employees, although there are differences in this trend in developed countries (Kakabadse, 2005). For small to medium-sized companies, human resources outsourcing is a strategy to reduce the responsibility of the company's internal staff in human resources, so as to focus more on their core business operations. By outsourcing the functions of the HR department, the company can acquire experienced and knowledgeable professionals, to improve employee relations, ensure company rules will be adhered to, and assist in terms of managing and reducing financing.

According to Komang \& Agus (2008) Outsourcing type is divided into two groups:

1) Business Process Outsourcing (BPO), in Indonesia this type is known as job vacancy. Outsourcing of this type refers to the desired end result. If a manufacturing company wants to transfer sales of its products to another company, then the payment of motivation is the number of units sold.

2) Outsourcing Human Resources. This outsourcing refers to the need for human resource provision and management, the manufacturing company will work with the providers that 
provide services for the provision and management of salespeople. Motivation to the provider company in the form of management fee as agreed.

According to Sharing Vision (2006) classify outsourcing to:

a. Outsourcing, is a delegation of operations or work that is not core (non core) which was originally done secuni iternal to external parties who have specialized to perform such operations. Outsourcing decisions are made in general to reduce costs or to increase focus on core competencies.

b. Off-Shoring, ie switching the work to another country. Off-Shoring can also mean outsourcing, if the work is transferred to another party. However, off-shoring may also not be an outsourcing if the company internally keeps on handling geographically transferred jobs to other countries.

c. Bussiness Process Outsourcing (BPO), ie the provision or management of processes for critical / non critical corporate applications by specialized specialty firms. Common examples of BPOs are call center, human resource management, accounting and payroll systems. BPOs can be explained by looking at application service providers (ASPs) where BPOs include software, process management, human resource procurement to operate the service, while ASP provides only the right to access and use certain features or functions provided by a software. ASP services are generally provided through the internet network.

As according to Indrajit (2000), by type of outsourcing information technology is differentiated in:

1) Total Outsourcing, ie companies tend to submit almost all the functions of information technology such as hardware, software, and brainware to other parties. Common examples that apply this model in Indonesia, are companies engaged in the manufacturing industry, mining, confection, and chemicals.

2) Total Insourcing, ie leasing or lending of human resources owned by other parties to be employed in related companies within a certain period of time. This type of outsourcing is widely used by large companies in Indonesia with multinational consulting firms that have a reputation in the field of information technology.

3) Selective Sourcing, companies do segregation of functions and business entities associated with information technology to be submitted partly to the provider.

4) De facto insourcing, ie delivery of information technology management to provider companies not because of objective evaluation results, but because of historical background.

\subsection{Outsourcing System Governance}

Corporate governance becomes an important issue in corporate management today. Corporate governance is a set of rules governing relationships between shareholders, managers of companies, creditor parties, governments, employees and other internal and external stakeholders related to their rights and obligations or a system governing and controlling the company (Cadbury Committee in Utama, 2004). The main risk of the contract system is 
moral hazard (Picot \& Wolff, 1994 in Bruttel, 2005). According to the theory of principal's agent, regarding the outsourcing system that cannot be separated from the contract system. Three governance mechanisms that reduce the risk of moral hazard are identified: incentive mechanisms, information mechanisms, and control mechanisms. The incentive mechanism focuses on the optimal design of the payment structure. Information mechanisms are mechanisms that utilize benchmarking and performance monitoring to increase stakeholder knowledge involved in outsourcing systems, whereas control mechanisms can be defined as broad legislation and government regulations that state in detail how service provider organizations should provide services (Ebers \& Gotsch, 1999 in Bruttel, 2005). The weakness of contractual arrangements is the dependence on one mechanism and the failure to understand the interdependence of the three (incentive, information, and control mechanisms). Combining these three mechanisms will be a key strategy as an effective management outsourcing requirement (Bruttel, 2005). In the labor system in Indonesia, the company can outsource the work or labor services, which can be done with the employment contract system with its employees, both the chartering company, the accepting company and the provider of labor services. The governance of outsourcing system in the perspective of industrial relations system (HI) involves various stakeholders and interconnected and various aspects of interaction interests between stakeholders. In general, the governance of outsourcing system is regulated in Law No. 13/2003 article 64-66 and article 56-60 and regulation of labor and transmigration minister (Permenakertrans) No 19/2012 and No $100 / 2004$.

\section{Outsourcing in Positive Law and Practice in Indonesia}

\subsection{Law of the Republic of Indonesia Number 13 Year 2003 about Employment}

The word outsourcing or outsourcing is not found in Indonesian legislation, but the meaning corresponding to the term and taking into account some of the above opinions and meanings can be found in several chapters in chapter ix employment relations act 13 of 2003 on employment. Outsourcing arrangements are mentioned jointly with the employment agreement, particularly in articles 64 to 66, in conjunction with article 1 number 15 jo Article 59 , namely the delivery of a portion of the execution of work to another enterprise. Ministry of manpower subsequently elaborated the provisions of the article by issuing decree of the minister of labor and transmigration (Kepmenakertrans) Number KEP.100/MEN/VI/2004, regarding Contract Workers / Outsourcing or Working Agreements of Certain Time (PKWT) jo. Kepmenakertrans No. Kep-101 / Men / VI / 2004 concerning Procedure of Licensing of Worker / Worker Service Company jo. Kepmenakertrans No. KEP.220 / MEN / X / 2004 on the terms of delivery of part of the implementation of work to other companies. Under article 64 of the manpower act, a company may enter into a labor agreement with a workforce to submit part of the work to another company through employment contracts or the provision of written services.

Regarding the outsourcing and the employment agreement, Law 13 of 2003 on manpower deals as follows: 


\section{Macrothink}

Case Studies in Business and Management

ISSN 2333-3324

2017, Vol. 4, No. 2

a. Article 56 distinguishes contractual agreements in two types, ie contracts for a certain time and contracts not for a specified time, whereby a work agreement for a certain period of time is based on a certain period of time and the completion of a particular job.

b. Article 57

1) Specifies the terms of the employment agreement for that particular time

2) Made in writing and must use Indonesian and Latin letters.

3) A work agreement for a specified time made in writing is contradictory to the provisions referred to in paragraph (1) shall be declared a working agreement for certain time of discharge.

4) In the case of an employment agreement made in the Indonesian language and a foreign language, if there is a convenience of different interpretations between the two, then the applicable work agreement is made in the Indonesian language.

c. Article 58 provides that a work agreement for a specified period of time may not require a probationary period of work.

d. Article 59

1) States that a work agreement for a certain period of time may only be made for a particular occupation which by type and nature or activity of its work shall be completed within a certain time, namely:

a. a job that is once completed or that is temporary in nature;

b. work that is expected to be completed in the not too distant future and for a maximum of 3 (three) years;

c. work that is seasonal;

d. work related to new products, new activities, or additional products that are still in trial or exploration.

2) A work agreement for a certain period of time may not be held for a fixed occupation.

3) The employment agreement for a certain time may be extended or renewed.

4) Certain time-based employment agreements are held for a maximum period of 2 (two) years and may only be renewed 1 (one) time for a maximum period of 1 (one) year.

5) An entrepreneur intending to extend such a specified period of employment, not later than 7 (seven) days before the expiration of a specific employment agreement has given its intent in writing to the worker concerned.

6) The renewal of a specified period of employment agreement may only take place after the expiration of 30 (thirty) days of the expiry of a certain long term employment agreement, the renewal of this particular period of employment shall only be made 1 (one) time and no later than 2 (two) years. 


\section{Macrothink}

Case Studies in Business and Management

ISSN 2333-3324

2017, Vol. 4, No. 2

7) Awork agreement for a certain time which does not meet the provisions referred to in this provision to be an indefinite time agreement.

e. Article 60

1) A work agreement for an indefinite period may require a maximum period of 3 (three) months' probation.

2) In the course of probation the employer shall be prohibited from paying of remuneration below the prevailing minimum salary.

f. Article 61 to Article 63, stipulates the terms of termination of the employment agreement, the transfer of the employment agreement and the employment relationship.

g. Article 64, a company may deliver a portion of the work execution to another company through employment contracts or the provision of services of workers in writing.

h. Article 65

1) The delivery of a portion of the work performed to another company shall be carried out through a written contracting agreement.

2) Work that may be transferred to another company as referred to in paragraph (1) shall meet the following conditions:

a. done separately from the main activities;

b. carried out by direct or indirect orders from the employer;

c. is a support activity of the company as a whole, and;

d. not hampering the production process directly.

3) Another company as referred to in paragraph (1) shall be a legal entity and further up to paragraph (9).

i. Article 66 (1) workers of a worker / labor service provider may not be used by the employer to undertake principal activities or activities directly related to the production process, except for the activities of supporting services or activities not directly related to the production process and thereafter up to paragraph (4).

Regard to the article of the article submitted, then there are several things, namely who the workers / laborers in question, what is a specific time agreement, and so forth. Noting the rules in article 56 that are related to the general provisions of PKWT according to ministerial decree no. 100 of 2004 concerning provisions of the Working Agreement of Particular Time (PKWT) is an agreement between worker / employer and employer to establish a working relationship within a certain time or for a particular job, while the worker herein by itself is not a permanent worker, but a worker / laborer who working only for a specified time under an agreement between workers and employers, and generally known as contract workers.

Payaman Simanjuntak said the PKWT is an agreement between worker / laborer and 
employer to carry out the work which is predicted to be completed within a relatively short period of time, the maximum duration is 2 years, and can only be extended once for the same length of time as the first working agreement, provided that all terms of (the) agreement shall not exceed three years. Further, it is said that PKWT is made for a period of 1 (one) year, then it can only be extended once with a maximum renewal period of 1 (one) year. When it is associated with article $1601 \mathrm{~b}$ of the civil code, outsourcing is a job-hiring agreement, whereby the contractor ties himself to complete a job for another party who buys by accepting certain payments and the contracting party binds himself to put the work to the party contractor with a certain fee.

The PKWT is a conditional agreement, which must be written and made in the Indonesian language, with the threat that if it is not made in writing and not made in the Indonesian language, it is considered as Permanent Working Task or Non-Specific Time Working Agreement (PKWTT) (article 57 paragraph (2) of Law of Manpower). In the PKWT may not be required any probationary period, and if in the agreement there is a probation clause, thereby if the termination of employment due to the probationary period is terminated, the employer shall be deemed to terminate the employment relationship before the expiration of the employment agreement. The entrepreneur in this case may be liable to sanctions to pay compensation to the worker / laborer at the wage of the worker / laborer until the deadline for the expiry of the period of the job.

PKWT cannot be held for permanent employment, pursuant to Section 59 above, PKWT may only be made for certain occupations which by type and nature or activity of the work shall be completed within a specified period of time, i.e., a once-completed work or temporary work . Work that the completion time is estimated in the not too long and maximum 3 years. The worker / laborer of the provider company specified in article 66 shall not be used by the employer to carry out the principal activities or activities directly related to the production process, except for the activities of supporting services or activities not directly related to the production process. The worker / laborer of the provider company is allowed to perform the supporting services work which is then given an explanation, is an activity outside the core business of a company, among others: cleaning service business, food supply business for catering workers, security officers (security / security units), supporting services business in mining and petroleum, as well as efforts to provide transportation of workers / laborers.

The employment agreement terminates when the employee dies, the expiration of the term of the employment agreement, the existence of a court decision and / or decision or determination of an industrial relations dispute settlement institution which has had permanent legal force, or the existence of certain circumstances or events specified in the employment agreement, or collective labor agreements that may result in the termination of employment relationship.

\subsection{Outsourcing General Practice in Indonesia.}

In today's economic growth, relatively many companies or factories stand and cause problems to recruit manpower directly in large numbers. The company or factory will then utilize an agency or public service bureau that can collect the necessary workforce. The 
service bureau originally had a simple structure, further specializing in the provision of manpower and becoming a provider of labor. On the workers' side, starting from non-technical workers or unskilled laborers such as maids, craftsmen and others, require employment, but do not know which companies are receiving labor as they are, on the other hand there is the development of labor-provider companies using information channels job vacancies not only in the labor market, but also office staff and well-trained technicians seeking employment through employment agencies.

The growth and development of employers' suppliers is rapidly affecting the market, both domestic and foreign markets, resulting in various implications for labor regulation and regulation on labor protection. As a democracy, Indonesia has issued a labor regulation that is responsive. Issues of legal adjustment to changes that occur in society, especially written law or legislation (in the broad sense). This is due to the static and rigid written legal weakness. Classical and dogmatic views tend to see passive law in change (Ahmad, 2002). The law is seen merely to conform to the changes occurring in its society, so that the law always awaits the changing needs of its people, then it also changes to be adapted to the changing needs of the people. This responsive and changing nature of the change creates a gap that can be used irresponsibly.

Problems in outsourcing practice in Indonesia, broadly divided into several main issues namely:

1) First, the problem lies in the status of the workers.

The root of the problems that arise regarding the status of workers in the implementation of outsourcing in Indonesia, workers have no clarity in the relationship, this resulted in the fulfillment of rights. Workers are required to meet requirements, heavy working hours, unbalanced wages, and lack of opportunities to join labor organizations, due to time spent in employment contracts. The relationship between workers and outsourcing companies and user companies is an unbalanced dependence relationship.

2) Secondly, the problem exists in the implementation of the granting of workers' rights.

Violation of the agreement will result in immediate dismissal by the management of outsourcing companies and replaced by other outsourced personnel. This condition frees the user industries from the obligations to the workers except to only provide wages from labor.

3) Third, the problems in the type of work that can be submitted.

On the issue of the type of work that can be submitted, each company has a different policy on the type of work submitted. This is due to differences in interests between the company and the labor associated with a particular interest. Differences of interests between companies and labor related to a particular interest. In the determination of the Business Process (including Core / Non-Core Activities) encountered constraints due to differences in the notion of non-core cores of each service user company, not all industries have associations on the other hand the regulator does not want to engage in corporate / labor issues and unfit associations identify the Business Process required by the related company. 
4) Fourth, the problem exists in the contractual relationship between the outsourcing company and the outsourcing user.

Eggi Sudjana conveyed, that the powers that pile up in the hands of the wage group in managing and controlling the limited resources. So in practice this dependency relationship works with one-sidedness, because the principle of maximizing profits emphasizes efficiency and productivity, resulting in labor exploitation.

5) Fifth, the problems contained in the outsourced labor itself.

Labor relations in the outsourcing system as mentioned above are very detrimental to the workers. Workers in the outsourced work model into the figure of goods traded cheaply. Labor is a factor of production after capital, the absence of labor results in the unlikely creation of capital accumulation. Celia Mather, reveals that outsourcing has resulted in three major problems: first, the elimination of labor from the table or negotiation agreement; secondly, the absence of corporate legal liability to labor; the third decrease of permanent labor so that all workers enter into outsourcing, labor conditions in uncertainty. User companies through service providers pay much lower wages than regular workers, avoiding the provision of benefits such as pensions, health insurance, death or accidents, paid sickness, paid leave, childbirth allowance.

In various print and electronic media and field interviews, it can be seen in relation to contractual relations between outsourcing companies and outsourcing service users are as follows:

1) There is a tendency of mutually beneficial cooperation between the service user and the provider company to the detriment of the worker. This is seen in some respondents who have outsourced employment status placed in the same company more than 5 years but each year change contract with outsourcing company.

2) For the employment agreement whose wages are included in the work agreement of the UMK, but the labor shall be deducted from the wage, the amount determined by the PPJP.

3) The target work system applied by outsourcing service user companies, which goes beyond the worker's ability.

4) Existence of overtime payments from outsourcing service user companies whose amount is lower than that of its permanent employees.

5) Outsourced employment may not enter the Workers' Union of outsourced service users.

6) Outsourcing providers do not have unions.

The problems encountered in the field associated with outsourcing labor conditions are as follows:

1) Lack of outsourced labor knowledge about the laws and regulations governing the implementation of the outsourcing system. 
2) Lack of understanding of contracts signed so that there is ignorance of labor rights that are not provided by the employment services company.

3) The existence of high economic demands resulted in labor by being compelled to accept whatever labor-provider companies and labor-intensive firms provided there was a considerable social gap.

4) The high desire of outsourced labor to the clarity of the status and the desire to become a permanent employee of outsourcing service users.

In the outsourcing work model there is a shift in the scope of industrial relations, known as tripartite or the relationship between workers, employers and the government. In the outsourcing model into four relationships i.e., laborers, outsourcing companies, user companies and governments. Outsourcing as the previous description has two types of outsourcing work related to job vacancy on the other hand, and human outsourcing. The second type of outsourcing is a practice that delivers efficiency to a certain extent in business operations, but seriously harms the interests of the workers, this practice is opposed by the labor movement in Indonesia.

\subsection{Problems Arising in the Implementation of Outsourcing}

Basically there are several objectives of the implementation of the outsourcing system, among others, to develop business partnerships, so that one company will not control an industrial activity. In the long period these activities are expected to be able to reduce the concentration of industrial activities in urban areas to be more evenly distributed to the regions (Priambada, \& Komang, 2008, p. 110). Implementing an outsourcing system also provides benefits to governments, communities and workers, and employers. For the government, outsourcing provides benefits, among others, to help develop and promote national economic growth, coaching and development of cooperative and small business activities, reducing the burden of municipal governments in the provision of public facilities such as transportation, electricity, water and public order.

For the community and workers, the outsourcing system provides benefits, among others, the activation of industry in the region will encourage the supporting economic activities in the community, develop the community's social infrastructure, work culture, discipline and increase economic capacity, reduce unemployment and prevent urbanization, companies in the community. For the company, the outsourcing system provides benefits such as improving the company's focus, exploiting world-class capabilities, sharing risks, resources alone can be used for other needs, creating fresh funds, reducing and controlling operating costs, and obtaining resources that are not self-owned (Yasar, \& Iftida, 2008, p. 15). The outsourcing system has opened up opportunities for new companies in the field of outsourcing services, and on the other hand has enabled companies that have stood for efficiency through the utilization of the services of outsourcing companies.

Since the enabling outsourcing system is regulated in the manpower act many companies are implementing it considering the company does not have to bother recruiting workers, train and so on because the authority has already been given to the company's service provider 
workers. The implementation of outsourcing system makes an anxiety for the workers outsourced because there is no guarantee of their working time and there is no certainty about the rights they receive. In addition, in the implementation of work in outsource is not only limited to work that is not related to the main activities but on the contrary that includes the work that is the main activity of the company. To apply or execute this outsourcing with very strict requirements in order to provide protection for the parties, especially the workers. This can be seen in the provisions of Articles 65-66. In accordance with the purpose and purpose of the establishment of a law itself that is for order, order, tranquility and protection. But there are some problems that arise in the implementation of outsourcing include:

a. Jobs that may be assigned to another company under Article 65 paragraph (2) as referred to in paragraph (1) shall meet the following conditions: Done separately from the main activities, conducted by direct or indirect orders from employers, company as a whole, does not impede the production process directly. In practice many companies do not pay attention because often occurs workers are placed on the main job of a company's activities. For example in the bank placed in the teller, costumer service, administrative staff, secretariat and others.

b. According to Article 65 paragraph (3) Other companies referred to in paragraph (1) shall be in the form of a legal entity and obtain permission from the government in this case the ministry of manpower. Terms of Legal Entity $(\mathrm{BH})$ turned out to have a violation because not all service providers companies that have legal entities exist that are not registered in the department of manpower or no business license. According to the Act if it is not $\mathrm{BH}$, the status of the working relationship is shifting to the employer. In reality working relationships are always contracts with service providers.

c. The status of working relationship in practice is always contract / working period of certain time, according to the provisions of article 59 paragraph 4 . Working agreements for a certain time based on a certain period can be held for a maximum of 2 (two) years and may only be extended 1 (one) time for a maximum period of 1 (one) year. in practice there is a period of time which makes for 1 year, already it is renewed again, for extension dismissed first 1 month after it is made again new contract. Extension of time is only for one time but in practice the worker is always extended his working time by making a new employment agreement. The consequence of this circumstance is that the worker's employment count will always be calculated from the beginning of the intention there is no increase in employment period which results in low wages, most social security for a maximum of 3 years with extension resulting in severance and reward calculation if terminated, pension, career path. The legal consequence of this situation is the strong reason for the plaintiffs of Electrical meter readers to file a lawsuit to the constitutional court to examine the provisions of time limit of work which consequently the constitutional court ruled that the work that has the object remains can no longer be done through the mechanism of contark or outsourcing with decision of the constitutional court number 27 / PUU-IX / 2011. The issuance of this decision, Article 65 Paragraph (2) and Article 66 Paragraph (2) sub-paragraph b of the manpower law shall not apply.

d. Out soursing, which is an agreement made between a company with a provider of labor services, for a particular job. Here the workers / laborers enter into their employment 
agreements not with the companies they work for, but they make their employment agreements with the employers' services companies. Similarly, the provision of wages-also provided by the company's service provider of such labor. They are usually contracted for two years, and can be extended for another year. So the duration is 3 Years. If the contract will be extended then he automatically become permanent worker, who works in the company. The problem is that the contract work time is continuously done, so it is very detrimental for workers / workers who are very weak. In addition to companies that commit violations, there is no provision of sanctions, so really very detrimental to workers / laborers in the outsourcing it. For example, outsourcing that uses a certain time work agreement. A certain time job agreement clearly does not guarantee job security, the survival of a worker's job, because a worker with a certain time labor agreement must know that at some point the employment relationship will be terminated and will not work there, consequently the worker will find another job. So that the sustainability of the work becomes a problem for workers who become outsourced workers with a certain time job review. If the job security is not guaranteed, then contrary to the constitutional guarantee get a decent job.

e. Working protection stipulated in the employment agreement is very minimal ie only in the form of wages in this case the highest minimum wage, rest period and social security Labor. The right of association and equal treatment with ordinary workers is not granted, so the right of association does not flourish. If there is a problem affecting the workers then the All Indonesian Workers Union can not help because it is not a member of the union.

\section{Conclusion}

In spite of the deviations occurring in the outsourcing practice in Indonesia, as can be known from those voiced in the various demonstrations that occur as well as at every international labor day celebration, outsourcing is a tangible form of the principle of labor market flexibility and can be found in almost all parts of the series of production processes. In addition, outsourcing is also defined as the transfer of some or all of the work and / or authority to other parties to support the strategy of using outsourcing services either personal, division of company or even a unit within the company.

In the dynamics of competitions that demand competitive advantage, the changing of competence demand that must be owned by labor can also be easily obtained by the company without having to go through the provision of education and training that require high cost but simply by looking for new workers who have competence in accordance with the needs of the company. Thus the company can maintain its competitiveness because it has a workforce that is always competitive but does not interfere with its financial performance.

The form of legal protection and labor rights is a repressive legal protection, the purpose being to resolve disputes. Departing from the concept of law on the formulation of legal norms contained in the provisions set in Law no. 13 Year 2003, the possibility of a dispute arising so as to cause a claim. The principle of recognition and protection of workers' rights stems from the recognition and protection of human rights. Between rights and obligations must contain equality or balance. Particularly to protect workers with certain time or outsourced contract labor, the provisions of article 6 are a very important provision to 
equalize treatment with permanent workers. According to this article, every worker / laborer is entitled to equal treatment without discrimination from the employer.

\section{Reference}

Ali, A. (2012). Menjelajahi Kajian Empiris Terhadap Hukum (p. 201). Kencana Prenada Media Group. Jakarta. 2012. pp. 201.

Belcourt, M. (2006). Outsourcing: The Benefits and the Risks. Human Resource Management Review, 16(2), 269-279. https://doi.org/10.1016/j.hrmr.2006.03.011

Bruttel, O. (2005). Contracting-Out and Governance Mechanisms in the Public Employment Service. (Discussion Paper). Bestell-Nr (DK): SPI.

Celia, M. (2008). Menjinakkan Sang Kuda Troya. Perjuangan Serikat Buruh Menghadang Sistem Kontrak/Outsourcing. Jakarta. TURC (Trade Union Right Centre).

Djumialdji. (2010). Perjanjian Kerja. Jakarta: Sinar Grafika.

Haines, R. (2009). Human Resource Management A Critical Approach: Organizational outsourcing and the implications for HRM. Routledge 2 Park Square, Milton Park, Abingdon, Oxon OX. 14 4RN.

Holcomb, T. R., \& Hitt, M. A. (2007). Toward a Model of Strategic Outsourcing. Journal of Operations Management, 25(2), 464-481. https://doi.org/10.1016/j.jom.2006.05.003

Indrajit, R. E. (2001). Sistem Informasi dan Teknologi Informasi. Jakarta: Gramedia.

Iftida Yasar, (2008). Sukses Implementasi, PPM Manajemen, Jakarta.

Kakabadse, N. K., \& Kakabadse, A. P. (2005). Discretionary Leadership; From Control/Co-ordination to Value Co-Creation. In C. L. Cooper (Ed.), Leaderships \& Management in the 21st Century (pp. 57-106). Oxford: Oxford University Press.

Karthikeyan, S., Bhagat M., \& Kannan, N. G. (2011). Making the HR Outsourcing Decision-Lessons from The Resource Based View of The Firm. IJBIT. 5.

Komang, P., \& Agus, E. M. (2008). Outsourcing versus Serikat Pekerja: An Intruduction to Outsourcing. Jakarta: Alihdaya Publishing.

Kremic, T., \& Tukel, O. I. (2003). Assisting public organizations in their outsourcing endeavors: a decision support model. Working paper, Cleveland State University, Cleveland, $\mathrm{OH}$.

Lacity, M., Willcocks, L., \& Rottman, J. (2008). Global Outsourcing of Back Office Services: Lessons, Trends, and Enduring Challenges. Outsourcing: An International Journal, 1(1), 13-34. https://doi.org/10.1108/17538290810857457

Martins, L. L., Gilson, L. L., \& Maynard, M. T. (2004). Virtual Teams: What do we know and where do we go from here? Journal of Management, 30, 805-835. https://doi.org/10.1016/j.jm.2004.05.002 


\section{Macrothink}

Case Studies in Business and Management

ISSN 2333-3324

2017, Vol. 4, No. 2

Ordanini, A., \& Silvestri, G. (2008). Recruitment and selection services: Efficiency and competitive reasons in the outsourcing of HR practices. The International Journal of Human Resource Management, 19(2), 372-389. https://doi.org/10.1080/09585190701799960

Pasolong, H. (2012). Metode Penelitian Administrasi. Bandung: Alvabeta

Payaman, J. S. (2001). Pengantar Ekonomi Sumber Daya Manusia Edisi 2001. Jakarta: FEUI.

Sharing Vision. (2006). Why Outsource. The Art of Partnership: Outsourcing Partnership \& SLA LPPM ITB.

Sriyono, D. S. (2013). Alih Daya di PLN. Makalah disampaikan dalam FGD Outsourcing: Sejuta Masalah dalam Pelaksanaannya di Indonesia. Fakultas Hukum Usahid Jakarta, 23 Oktober 2013.

Subekti, R., \& Dan R. T. (2003). Kitab Undang-undang Hukum Perdata (KUH Perdata), Pradnya Paramita, Jakarta.

Sudjana, E. (2002). Buruh Menggugat. Persfektif Islam. Jakarta: Pustaka Sinar Harapan.

Sutedi, A. (2009). Hukum Perburuhan. Jakarta (ID): Sinar Grafika.

Utama, M. (2004). Komite Audit, Good Corporate Governance dan Pengungkapan Informasi. Jurnal Akutansi dan Keuangan Indonesia. Departemen Akutansi FEUI. 1, 61-79.

\section{Legislation:}

Law no. 2 of 1992 on Social Security of Labor

Law No.13 of 2003 on Manpower

Law no. 21 of 2000 on Trade Unions

Law no. 2 Year 2004 on Industrial Relations Dispute Settlement.

\section{Copyright Disclaimer}

Copyright for this article is retained by the author(s), with first publication rights granted to the journal.

This is an open-access article distributed under the terms and conditions of the Creative Commons Attribution license (http://creativecommons.org/licenses/by/3.0/). 